\title{
Design of Learning Activities using Rigorous Mathematical Thinking (RMT) Approach in Application of Derivatives
}

\author{
Dayat Hidayat ${ }^{1}$, Ahmad Wachidul Kohar ${ }^{2}$, Nina Rinda Prihartiwi ${ }^{3}$, Husni Mubarok ${ }^{4}$, \\ Abebayehu Yohannes ${ }^{5}$ \\ 1,2,3 Mathematics Department, Universitas Negeri Surabaya, Surabaya, Indonesia \\ ${ }^{4}$ National Taiwan University of Science and Technology, Taipei, Taiwan \\ ${ }^{5}$ Wolaita Sodo University, SNNP Region, Ethiopia
}

\begin{tabular}{|c|c|}
\hline (A) Check for updates open 0 access CC & DOI : $\underline{\text { https://doi.org/10.46245/ijorer.v2i1.75 }}$ \\
\hline Sections Info & ABSTRACT \\
\hline Article history: & \multirow{10}{*}{$\begin{array}{l}\text { Learning design is one of the factors that support the learning process in } \\
\text { order to achieve learning objectives in all subjects including mathematics. } \\
\text { Many approaches can be employed by a teacher in making learning } \\
\text { design, one of which is rigorous mathematical thinking (RMT) approach. } \\
\text { The RMT approach puts forward students actively in constructing their } \\
\text { knowledge through the use of psychological tools and mediation. This } \\
\text { article reports a set of learning activities designed through a } \\
\text { developmental study using the RMT approach in the topic of application } \\
\text { of derivatives. Participants of this research were twenty-six of 11th grade } \\
\text { students from a private secondary school. Data were collected through } \\
\text { written test and classroom observation. The research instruments were } \\
\text { student worksheet and observation sheet. In the learning process, } \\
\text { students use psychological tools to connect their previous knowledge to } \\
\text { the material being studied. This makes students able to construct their } \\
\text { own knowledge more thoroughly. On the other hand, with the mediation } \\
\text { carried out by the teacher, students can focus more and understand each } \\
\text { material well and bridge the conceptual errors. Based on the results of the } \\
\text { study and some literature, Design of learning activities using Rigorous } \\
\text { Mathematical Thinking (RMT) on application of derivative can be an } \\
\text { alternative as effective learning. }\end{array}$} \\
\hline Submitted: December 21, 2020 & \\
\hline Final Revised: January 15, 2021 & \\
\hline Accepted: January 20, 2021 & \\
\hline Published Online: January 31, 2020 & \\
\hline Keywords: & \\
\hline Application of derivatives & \\
\hline Learning activities & \\
\hline Rigorous Mathematical Thinking & \\
\hline 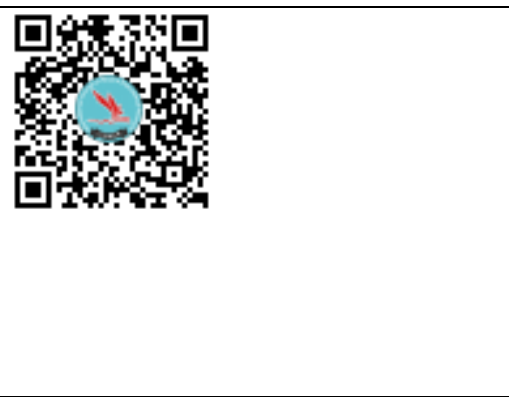 & \\
\hline
\end{tabular}

\section{INTRODUCTION}

The derivative concept and its application in real life is one of the essential mathematical material in high school and college students. However, there are still many difficulties students have in understanding and solving problems related to derivatives. The difficulty is mostly because students are not able to understand the derivative concept well (Tall, 2011). Moreover, Hashemi et al. (2014) inform that the weakness of making connection between graphical and symbolic aspects of the concepts was a difficulty for most students in the learning of derivation. It seems apparent that most students only memorize instructions and remember algebraically without relating the function graph as visual representation. In fact, Van Garden and Montague emphasize that visual representation by students has a positive correlation on mathematical problem solving (Van Garderen \& Montague, 2003). Therefore, it needs a learning design that is able to facilitate students well to understand the concept of derivatives and its application.

One of the mathematical approaches that facilitates students in using visual representation for deep understanding is rigorous mathematical thinking (RMT). The 
Design of Learning Activities using Rigorous Mathematical Thinking (RMT) Approach in Application of Derivatives

RMT paradigm based on two main theories: theory of psychological tools from Vygotsky and theory of mediated learning experience (MLE) from Feuerstein. The RMT implies that cognitive processes are formed through appropriation, internalization, and utilization of psychological tools through the application of MLE interactional dynamic (Kozulin \& Kinard, 2008). Furthermore, RMT can be interpreted as mental operation to acquire insights about patterns and relationship, to elaborate these insights for their organization to form emerging conceptualizations and understandings, and then to transform and generalize these emerging conceptualizations and understanding into coherent, logically-bound ideas and networks of ideas (Kinard \& Kozulin, 2006). Therefore, the use of psychological tools at the RMT allows students to be involved in designing visual representations as a method to organize and shape relationships based on data received through mathematical reasoning (Kozulin \& Kinard, 2008). Hidayat et al. (2017) suggest that RMT emphasizes the mediation between teacher and student which results in a good understanding of matter to be transformed further conceptually through interrelated ideas.

Several studies related to RMT have been conducted. Some studies discuss RMT as a level of cognitive function and others discuss RMT as a learning approach. Research on RMT as a level of cognitive function has been carried out on various topics such as geometry (Nugraheni et al., 2018; Yunita et al., 2019), Integer and fraction (Resmi \& Caswita, 2020) and real analysis (Firmasari et al., 2019). As an approach, previous research shows some positive results supporting students' improvement on particular topics in mathematics. For example, Hendrayana (2017) reported that students' conceptual understanding who obtain RMT approach is better than those who obtain direct learning. In addition, Hidayat et al. (2017) concluded that RMT approach can also improve a better achievement of students' mathematical creative and critical thinking abilities rather than expository approach. Previous studies have not explained qualitatively about learning design using the RMT approach, especially on the topic of application of derivatives. Furthermore, studies on difficulties in studying derivatives have been discussed (Hashemi et al., 2014) such as weaknesses in connecting graphical and symbolic aspects. However, it is not discussed in detail how aspects of graphs can help students in solving problems related to derivatives. This study explains the relationship between RMT and the use of psychological tools to help students to build knowledge through graphical and algebraic aspects in the same time.

Therefore, purpose of this study is to describe qualitatively the design of mathematics learning activities using the RMT approach in the topic of the application of derivative as well as the student response description. The results and findings of this study can be a reference for teachers in designing learning activities in the topic of application of derivative.

\section{THEORITICAL BACKGROUND}

\section{Learning activities}

Learning is conceived as an active, constructive, collaborative, and context-bound activities (Kwakman, 2003). This activity aims to provide an effective experience for students in building their own knowledge and gaining a thorough understanding of the material discussed. Current theory assume that students learn best when they have opportunity to actively construct their own knowledge (McLaughlin, 1997). In order for 
Design of Learning Activities using Rigorous Mathematical Thinking (RMT) Approach in Application of Derivatives

student to construct their own knowledge, teacher should stimulate students to engage in learning environment that focus on active and constructive activities. Thus, the teacher must plan and organize learning activities that are good in facilitating students to gain a deep understanding of a material.

\section{Theory of Psychological Tools}

Mathematical specific psychological tools are developed from general psychological tools from Vygotsky in 1979. These tools are symbolic artifacts-signs, symbols, texts, formulae, and graphic-symbolic devices. Kinard and Kozulin reveal that some tools that are specific psychological tools are symbols and code, number system, table, number line, Cartesian coordinate system (Kinard, 2007). Regarding to Utilization of psychological tools, students can organize their knowledge well and support mathematical generalizations and abstractions.

\section{Theory of Mediated Learning Experience (MLE)}

Theory of mediated learning was developed by Feuerstein in 1980. He suggested that mediated learning experience (MLE) reflect the quality of interaction between the learner, the material, and the human mediator. There are three criteria of mediation which are important to meet the best quality of interaction. These criteria are intentionality/reciprocity, transcendence, and mediated of meaning. Intentionality/reciprocity means that the mediator should attract and keep student's attention and engagement to the task. Transcendence means that mediator should establish the way for bridging students to relate their prior knowledge and the task. Mediated of meaning means that mediator should make students understand the motivation behind each step of learning activity and become self-directed learner. The primary roles of MLE is to guide students establish the basis for efficient learning and problem solving strategies (Kozulin \& Kinard, 2008).

\section{Rigorous Mathematical Thinking (RMT) as an approach in Mathematical Classroom}

RMT as an approach means that the use of mediated learning experience (MLE) theory and psychological tools theory in learning activities. The RMT application focuses on mediation for students to be involved in the construction of mathematical concept using three phases: Cognitive development, Content as process development, and Cognitive conceptual construction practice. Cognitive development phase is the phase where the teacher mediates students to appropriate the structure of cognitive tasks with psychological tools based on previous experience. Content as process development is the phase where the teacher mediates students to discover and formulate mathematical pattern and relationship through the use of psychological tools to construct mathematical understanding. Cognitive conceptual construction practice is the phase where the teacher mediates student to practice the use of psychological tools to organize the use of cognitive functions to solve cognitive exercise. The RMT process reflect a quality of learning which aims to engage all learners to construct mathematical conceptual learning with deep understanding (Kozulin \& Kinard, 2008). When precise understanding is achieved, students become able not only to be involved in solving certain problems but also reflective thinking. 


\section{METHOD}

This study uses quasi-experimental research methods. However, this paper does not discuss the statistical results on examining the effectiveness of the RMT approach as reported in previous study (Hidayat et al., 2017). Instead, this paper reveals that learning design descriptively. The learning design describes learning activities between students and teacher supported by students' responses on the task corresponding to each of RMT phases sequentially. Participants of this research were twenty-six 11th grade students from a private secondary school in Bandung. The participants selected by considering the heterogeneity of the class background in term of gender and mathematical ability. Data were collected through written test and classroom observation. The research instruments were student worksheet and observation sheet. Data were analyzed by comparing the actual activities experienced by the student participants and the activities expected within RMT activities theoretically. The discussion aims to know about student learning activities through rigorous mathematical thinking (RMT) approach on the subject of the application of derivatives. The description of learning activities in this paper includes a description of learning with a rigorous mathematical thinking approach.

\section{RESULTS AND DISCUSSION}

\section{Phase I Cognitive Development}

In this phase, students were mediated to adjust cognitive tasks with psychological tools. First, the teacher mediates students by giving an explanation of the big picture of the material that will be studied to students. It aims to keep students intentionally involved in the learning process. Next the teacher provides a worksheet that refers to the RMT approach to students who have formed a small group. The worksheets provided aim to enable students to understand the derivative meanings as the slope of the tangent line. The teacher monitors the needs of students in answering the worksheets given. Mediation of transcendence is carried out by the teacher in the form of questions and answers to students regarding matters relating to the ability of prerequisites such as gradient formulas and limit concepts. Some students can immediately remember and respond well. However, others did not answer and try to remember. The essence of this phase is that students are given experience to find derivative meanings on the curves at a certain point with psychological tools through tangent line.

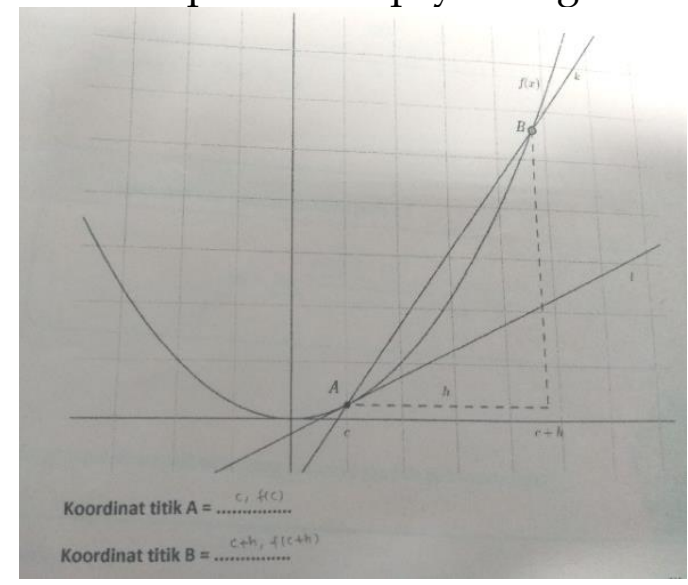

(a)

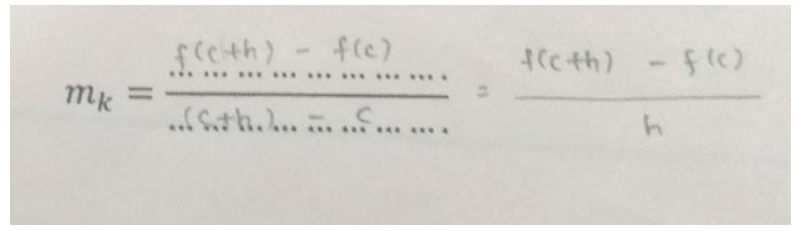

(b)

Figure 1. Student appropriate psychological tools to their cognitive function. 
Design of Learning Activities using Rigorous Mathematical Thinking (RMT) Approach in Application of Derivatives

The student response above shows how students use their cognitive functions to know the coordinates of points A and B (Figure 1a) and form a slope of line $k$ through points A and B (Figure 1b). After that, the teacher gives mediation by asking whether the gradient $k$ will be the same as the line gradient $l$. Some students do illustrations in a worksheet and answer conditions that are met when $h=0$ or $c+h=c$ (Figure 2a).

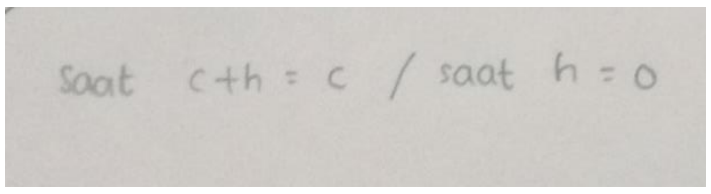

(a)

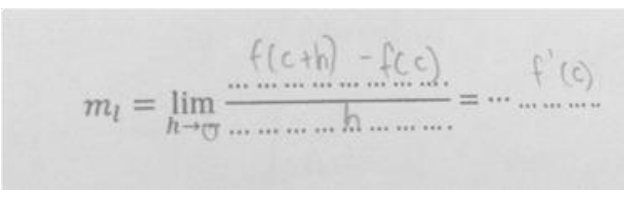

(b)

Figure 2. Students' response.

Next students represent in the form of limits and connect with algebraic definitions of derivative that they have learned at the beginning of the derivative chapter (Figure $2 b)$. After that students write a conjecture on the worksheet.

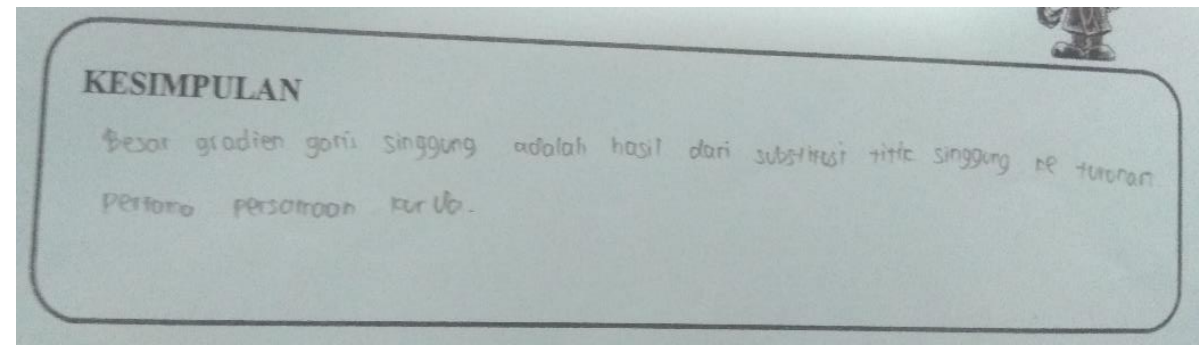

(a)

KESIMPULAN

Besamya gradien ditentukan oleh turunan pertama fungsi tersebut

(b)

Figure 3. Students' conjecture.

There are differences at the conjecture of each group, most of which answer that the slope of the tangent line at certain point was the result of substitution absis of the point to the derivative of the function of the curve (Figure 3a). However, some of them cannot conclude completely (Figure 3b). Mediated of meaning is given by teacher to student in the term of confirming all students understand about what the slope of the tangent line means and why and how it is related to derivative. Moreover, teacher highlighted the importance of understanding the slope of the tangent line to solve problems related to maximum and minimum.

The experience of students in understanding the relationship between the slope of tangent line and derivative concepts is very valuable. This can provide a large scheme in the brain that is interrelated between one idea and another. Some references state that students' understanding of the slope of tangent line is more instrumental without knowing the meaning of the relationship with derivative concepts (Sahin et al., 2015). 
Therefore, by providing direct experience to students using psychological tools in the form of Cartesian coordinates and graphs very helpful in cognitive development for organizing the big idea of the relationship between the slope of tangent line with derivative concept. In addition, Mielicki \& Wiley (2016) suggest that graphical representations, in this study are psychological tools, can help students informally in their lack of understanding the slope concept. This is because most students understand the slope material related to its graphic representation (Nagle et al., 2013).

\section{Phase II Content as Process Development}

In this phase students are mediated to find and formulate patterns or relationships between cognitive tasks and psychological tools in the form of tangent curves in the Cartesian coordinates that were previously understood. The teacher mediates by giving scaffolding to students in finding the relationship and ensuring that each student is involved in the process.

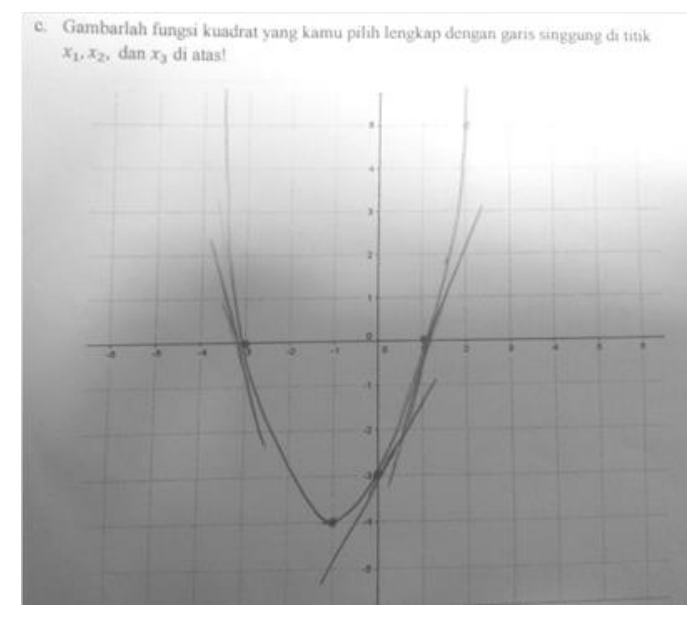

Figure 4. Student use psychological tools

In the Figure 4 it appears that students are given experience to draw a graph of a function and choose a number of points along with drawing a line to observe and find a pattern or characteristic of an increasing and decreasing function (Figure 5).

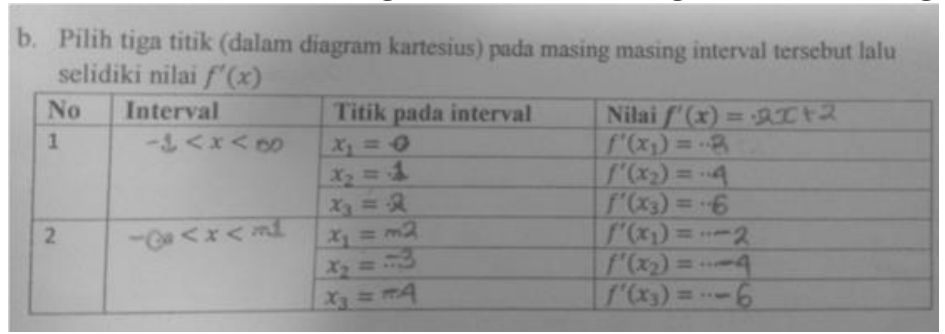

Figure 5. Students' response

After that, students write a conjecture to find out whether a function is decreasing or increasing. In this section, all students have same conjecture that a function increasing when $f^{\prime}\left(x_{i}\right)>0$ and decreasing when $f^{\prime}\left(x_{i}\right)<0$ (Figure 6a) and some groups complete with the illustration of the line graph as shown in the Figure $6 \mathrm{~b}$. 
Design of Learning Activities using Rigorous Mathematical Thinking (RMT) Approach in Application of Derivatives

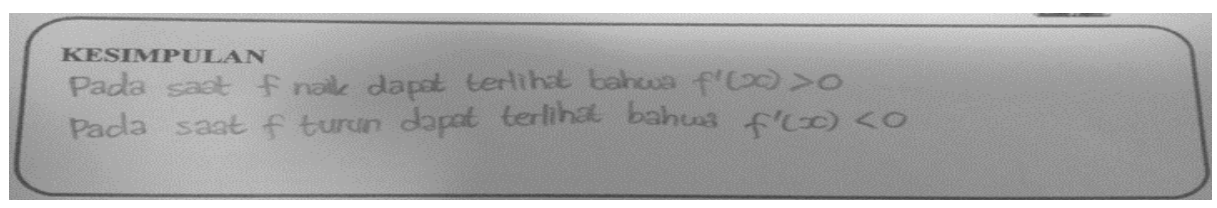

(a)

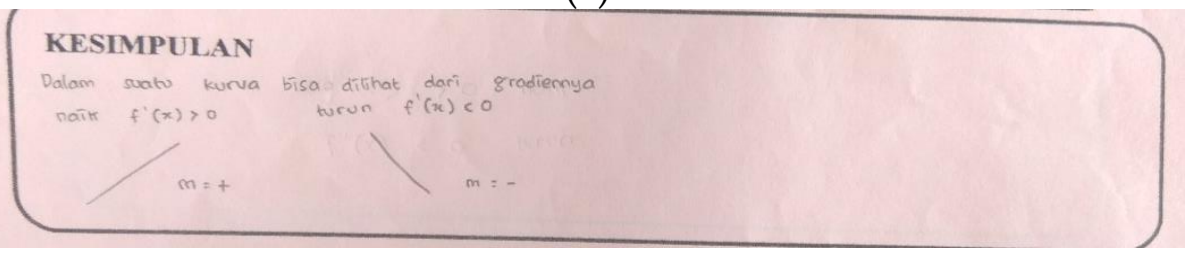

(b)

Figure 6. Students' conjecture.

Next the teacher mediates the trend of what if $f^{\prime}\left(x_{i}\right)=0$. Some students answered that they did not increasing or decreasing. Furthermore, the teacher informs that the situation referred to as a turning point is one possibility in determining the local maximum and minimum values. Students' understanding of making conjecture for increasing and decreasing function is better when students makes connection with the concept of slope of tangent line that they have understood. This happens because Rigorous mathematical thinking approaches facilitate students making connection in forming a deep understanding of relationships through the use of psychological tools. These connections are needed by students as explained by Adu-Gyamfi et al. (2017) in his research that it is very important to know how students make connections, what kinds of connections are made, and how to change learning practices in helping students make these connections in understanding mathematical concepts. If mathematical concept understood relationally, students may compartmentalize the big ideas related to the concept in their conceptual system (Sahin et al., 2015).

\section{Phase III Cognitive Conceptual Construction Practice}

In this phase students are mediated to be able to use psychological tools to organize their cognitive functions in mathematical problem solving. Some mathematical questions are given in the worksheet to be worked on and discussed by each group. The following is an example of two student responses to questions.

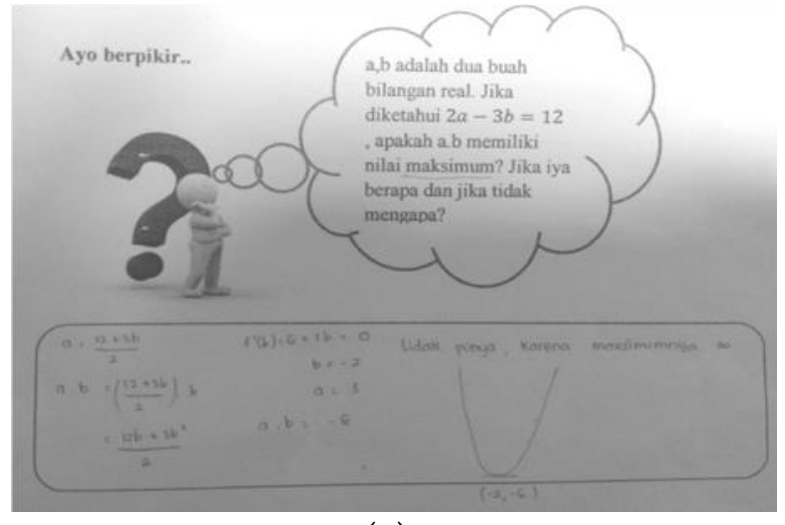

(a)

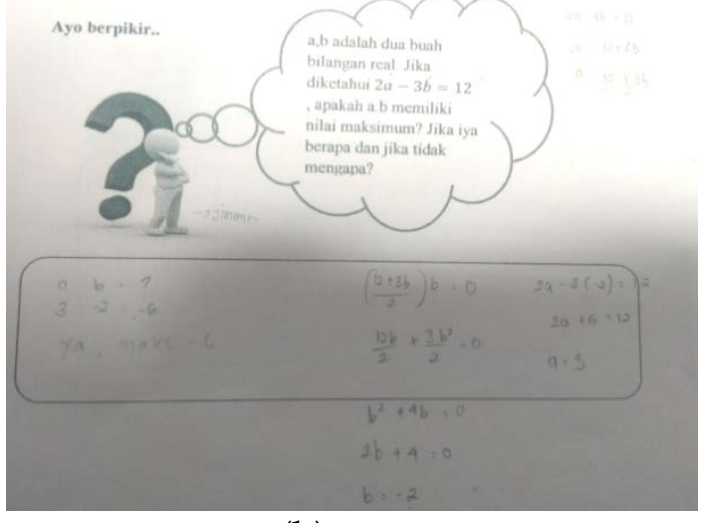

(b)

Figure 7. (a) Student's answer with graph illustration (b) Student's answer without graph illustration 
Design of Learning Activities using Rigorous Mathematical Thinking (RMT) Approach in Application of Derivatives

Most students answer algebraically and complete using graphs (Figure 7a). However, there are still students who think that $a b$ has maximum value (Figure $7 b$ ). This shows that some students still have difficulty in connecting the use of graph in determining maximum-minimum concepts.

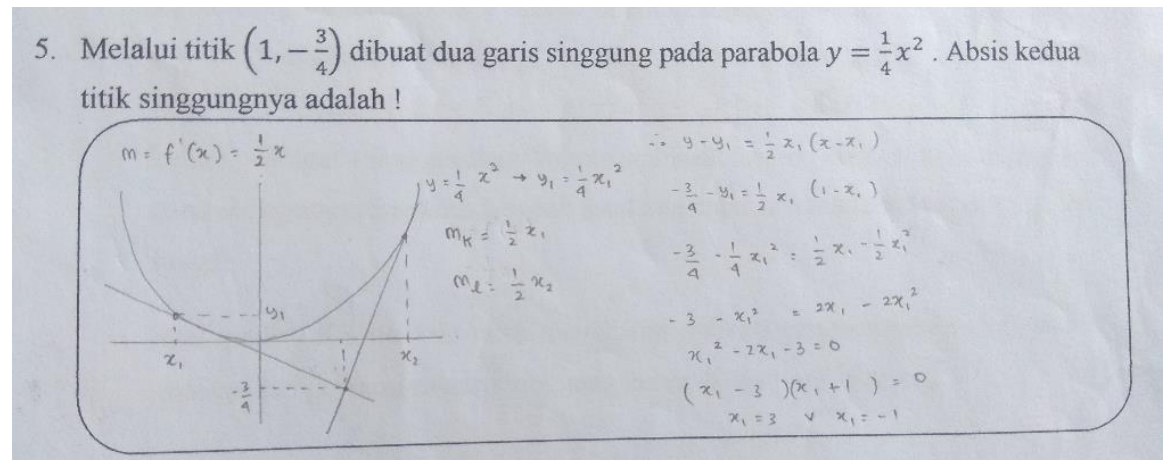

(a)

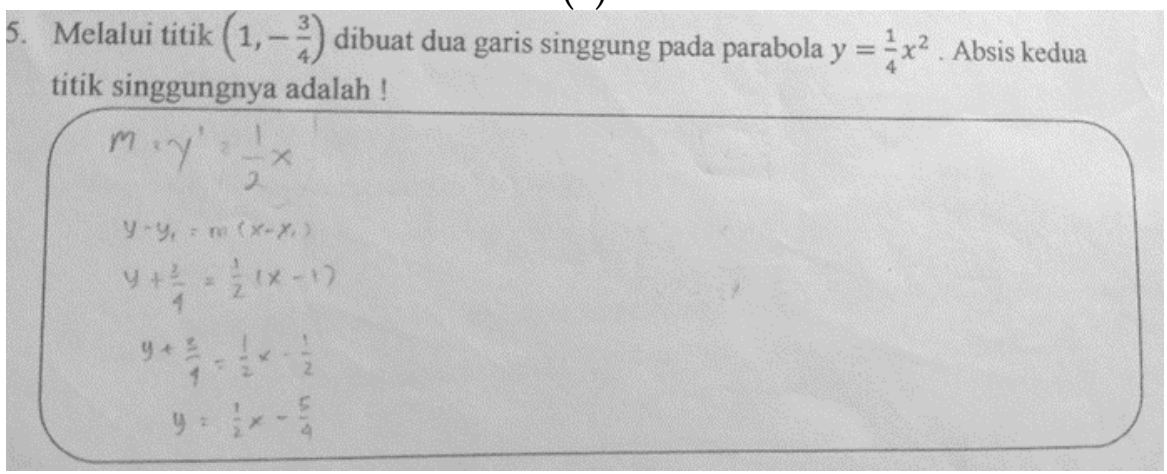

(b)

Figure 8. (a) Student uses psychological tools to formulate solution (b) Student does not use psychological tools to solve problem

Figure 8a shows students using psychological tools to understand problems and relate the knowledge they already know in formulating solutions to the problem. On the other hand, Figure $8 \mathrm{~b}$ shows students without using psychological tools trying to formulate problem solving. It is seen that students are confused in formulating problem solving because they assume that the point known is the tangent point. Students who have a deep understanding of tangent curves and can use psychological tools well will be able to plan problem solving. This is of course because a deep understanding of the relevance of the material will make students fluently develop problem solving strategies. In line with research conducted by Fransisco (2013), which is reported that high school students recognize that mathematical understanding is a key aspect of knowing mathematics. In addition, the use of psychological tools in the form of Cartesian coordinates and graphs can make it easier for students to represent visually the problems faced and to arrange the resolution of the problem. Conversely, students who do not have the understanding to associate material and not use psychological tools will be difficult in formulating problem solving. This is due to the lack of visual representations of objects understood by students so that students are unable to formulate problem solving. Whereas, visual representations can be another important representation to designate or communicate mathematical concepts and promote a 
Design of Learning Activities using Rigorous Mathematical Thinking (RMT) Approach in Application of Derivatives

successful solution of problems taking advantages as a tool and helping students to argue their answers (Garcia \& Flores, 2019).

\section{CONCLUSIONS}

Design of learning activities using Rigorous Mathematical Thinking (RMT) on application of derivative can be an alternative as effective learning. There are two things that make this design able to improve students' cognitive development. First of all, the RMT is able to provide good quality interactions between student, teacher, and material. This is reflected in the three main pillars of mediated learning experience (MLE) which are intentionality/reciprocity, transcendence, and mediated of meaning. Regarding to that, the focus and participation of students in the learning process can be achieved well. The second, psychological tools in RMT could establish conceptual understanding of students for learning application of derivative. Graph and Cartesian coordinates as psychological tools could help student to make visual representation and use both geometry and algebra aspect in learning derivative. This study is limited to a description of the mathematics learning design on the application derivatives material with a fundamental rigorous mathematical thinking approach. For future research, design research can be the right choice to identify in-depth difficulties and develop a good hypothetical learning trajectory.

\section{REFERENCES}

Adu-Gyamfi, K., Bossé, M. J., \& Chandler, K. (2017). Student connections between algebraic and graphical polynomial representations in the context of a polynomial relation. International Journal of Science and Mathematics Education, 15(5). https:// doi.org/10.1007/s10763-016-9730-1.

Firmasari, S., Sulaiman, H., Hartono, W., \& Noto, M. S. (2019). Rigorous mathematical thinking based on gender in the real analysis course. Journal of Physics: Conference Series. 11574 (042106). https://doi.org/10.1088/1742-6596/1157/4/042106.

Francisco, J. M. (2013). The mathematical beliefs and behavior of high school students: Insights from a longitudinal study. The Journal of Mathematical Behavior, 32(3), 481493. https:// doi.org/10.1016/j.jmathb.2013.02.012.

García-García, J., \& Dolores-Flores, C. (2019). Pre-university students' mathematical connections when sketching the graph of derivative and antiderivative functions. Mathematics Education Research Journal, 1-22. https:/ / doi.org/10.1007/s13394-019$\underline{00286-x}$.

Hashemi, N., Abu, M. S., Kashefi, H., \& Rahimi, K. (2014). Undergraduate students' difficulties in conceptual understanding of derivation. Procedia-Social and Behavioral Sciences, 143, 358-366. https://doi.org/10.1016/j.sbspro.2014.07.495.

Hendrayana, A. (2017). Pengaruh pembelajaran pendekatan rigorous mathematical thinking (RMT) terhadap pemahaman konseptual matematis siswa SMP. Jurnal Riset Pendidikan Matematika, 4(2), 186-199. https://doi.org/10.21831/jrpm.v4i2.15385.

Hidayat, D., Nurlaelah, E., \& Dahlan, J. A. (2017). Rigorous mathematical thinking approach to enhance students' mathematical creative and critical thinking abilities. In Journal of Physics: Conference Series, 895 (012087). https://doi.org/10.1088/1742-6596/895/1/012087. 
Design of Learning Activities using Rigorous Mathematical Thinking (RMT) Approach in Application of Derivatives

Kinard, J. (2007). U.S. Patent Application No. 11/584,367.

Kinard, J. T., \& Kozulin, A. (2006). Creating rigorous mathematical thinking: a dynamic that drives mathematics and science conceptual development. Transsylvanian Journal of Psychology-Erdély Pszichológiai Szemle, 2, 251-266.

Kozulin, A., \& Kinard Sr, J. T. (2008). Rigorous mathematical thinking: Conceptual formation in the mathematics classroom. New York: Cambridge University Press. https://doi.org/10.1017/cbo9780511814655.

Kwakman, K. (2003). Factors affecting teachers' participation in professional learning activities. Teaching and Teacher Education, 19(2), 149-170. https:/ / doi.org/10.1016/s0742-051x(02)00101-4.

McLaughlin, M. W. (1997). Rebuilding teacher professionalism in the United States. Beyond educational reform: Bringing teachers back in, 77-93. https:// doi.org/10.1108/ijem.1998.12.5.240.1.

Mielicki, M. K., \& Wiley, J. (2016). Alternative representations in algebraic problem solving: When are graphs better than equations? The Journal of Problem Solving, 9(1), 3-12. https:// doi.org/10.7771/1932-6246.1181.

Nagle, C., Moore-Russo, D., Viglietti, J., \& Martin, K. (2013). Calculus students' and instructors' conceptualizations of slope: A comparison across academic levels. International Journal of Science and Mathematics Education, 11(6), 1491-1515. https:/ / doi.org/10.1007/s10763-013-9411-2.

Nugraheni, Z., Budiyono, B., \& Slamet, I. (2018). The impact of rigorous mathematical thinking as learning method toward geometry understanding. Journal of Physics, Conference Series, 1013(012121). $\quad$ https://doi.org/10.1088/1742$6596 / 1013 / 1 / 012121$.

Resmi, R. A. (2020, June). Implementation of lesson study with rigorous mathematical thinking based on student worksheet to enhance the students' mathematical critical thinking. Journal of Physics: Conference Series, 1563 (012059) https://doi.org/10.1088/1742-6596/1563/1/012059.

Sahin, Z., Yenmez, A. A., \& Erbas, A. K. (2015). Relational understanding of the derivative concept through mathematical modeling: A case study. Eurasia Journal of Mathematics, Science $\mathcal{E}$ Technology Education, 11(1). https://doi.org/10.12973/eurasia.2015.1149a.

Tall, D. A. V. I. D. (2011). Looking for the bigger picture. For the Learning of Mathematics, $31(2), 17-18$.

Van Garderen, D., \& Montague, M. (2003). Visual-spatial representation, mathematical problem solving, and students of varying abilities. Learning Disabilities Research $\mathcal{E}$ Practice, 18(4), 246-254. https:// doi.org/10.1111/1540-5826.00079.

Yunita, D. R., Maharani, A., \& Sulaiman, H. (2019, April). Identifying of rigorous mathematical thinking on olympic students in solving non-routine problems on geometry topics. In 3rd Asian Education Symposium (AES 2018). Atlantis Press. https://doi.org/10.2991/aes-18.2019.111. 
Design of Learning Activities using Rigorous Mathematical Thinking (RMT) Approach in Application of Derivatives

*Dayat Hidayat (Corresponding Author)

Department of Mathematics,

Universitas Negeri Surabaya,

Kampus Ketintang, Jalan Ketintang, Gedung C8, Surabaya 60231

Email: dayathidayat@unesa.ac.id

\section{Ahmad Wachidul Kohar}

Department of Mathematics,

Universitas Negeri Surabaya,

Kampus Ketintang, Jalan Ketintang, Gedung C8, Surabaya 60231

Email: ahmadkohar@unesa.ac.id

\section{Nina Rinda Prihartiwi}

Department of Mathematics,

Universitas Negeri Surabaya,

Kampus Ketintang, Jalan Ketintang, Gedung C8, Surabaya 60231

Email: ninaprihartiwi@unesa.ac.id

\section{Husni Mubarok}

Graduate Institute of Digital Learning and Education, National Taiwan University of Science and Technology

No. 43號, Section 4, Keelung Rd, Da'an District, Taipei City, 106 Taiwan

Email: husnimubarok254@gmail.com

\section{Abebayehu Yohannes}

Department of Mathematics, College of Natural and Computational Science, Wolaita Sodo University

Wolaita Sodo, SNNP Region, 138 Ethiopia

Email: abex98@gmail.com 